\title{
THE PROBLEMS OF FOREST PATHOLOGY IN QUEBEC ${ }^{1}$
}

\section{By ReNÉ POMERLEAU}

Director, Division of Forest Pathology, Department of Lands, 2uebec.

With the continuous and fast recession of the primitive and accessible forest, the ever-increasing demand for forest products and, for the time being, the wide-open gaps in our wooded areas resultig from the world war, all factors contributing to reduce the production of wood must be given more attention. Among these factors tree diseases may be classified as one of the most serious.

To gain a proper insight into the problems of tree diseases in Quebec and other losses resulting from pathological causes it is essential to have at least a general view of the present forest status within this territory.

\section{STATISTICS}

\section{FOREST SITUATION}

Of a total area of nearly 600,000 square miles a little more than 250,000 square miles of the Province of Quebec may be considered as forest land (Bédard 1944 b). Part of this territory, roughly 40,000 square miles, belongs to cultivated areas two-thirds of which are still kept as woodland. Of course, these vast areas are not all covered with merchantable stands and large surfaces are still occupied by young growth or are denuded.

In volume it is estimated that the accessible area contains more than 164 billion cubic feet, and the inaccessible area 40 billion cubic feet. Seventy-five per-cent of the volume of merchantable timber is softwood, the bulk of which is composed of spruce and balsam fir.

The annual wood consumption derived from these forest lands is estimated at more than 1,445 million cubic feet, 750 million cubic feet of which are taken out by cutting operations and more than 300 million cubic fee by fire, insects and diseases (Rousseau 1944). The annual growth is estimated at about 1,500 million cubic feet.

\section{FOREST TYPES}

A brief description of the main forest types or classes will serve the present purpose. In Halliday's (1937) forest classification we find the Canadian or boreal coniferous forest extending north of a line which roughly follows the Ottawa and St. Lawrence rivers. This type of forest is gradually replaced by a taiga wihch is finally followed much further north by the artic tundra (Dansereau 1944a). The Canadian forest is largely composed of black spruce and balsam fir, but white spruce, jack pine, tamarack, white birch and aspen occupy certain sites or are secondary associates.

South of the main division occupied by the bulk of the population and where agriculture thrives the land is mainly covered by a deciduous forest. On the best sites the forest cover is made up mostly of sugar maple and

\footnotetext{
1. Lecture delivered before the Plant Science Club at Yale!University, New Haven, Conn.,
} February 5th, 1945. 
beech (Dansereau 1944b). Yellow birch and red maple tend to occupy more humid situations. These broadleaf forests which extend far south into the United States alternate locally with coniferous stands in a checkerboard pattern, the latter occupying the coldest and dampest sites (Dansereau 1944a). Various associations are to be found successively on the same area in its evolution towards the climatic forest. Besides the main species the following trees occur in varying proportions according to sites: white and grey birch, red, white and black spruce, white and red pine, cedar, tamarack, clm, red oak, poplar, ash.

\section{UTILISATION}

A general view of the use being made of this vast natural resource will also cast light on the status of forestry in Quebec. The biggest logging operations both in the Canadian forests and in the coniferous stands of the southern area are in softwoods. Spruce and balsam fir are largely used for the manu. facture of pulp and paper. Crown lands furnish the bulk of the raw material. Jack pine, white pine, and yellow birch rank next as commercial species but they are utilized on a much smaller scale. Other species, such as cedar, hemlock, red pine, white birch, maple and aspen are again commercially less important. It is to be remembered, however, that yellow birch, white birch and aspen have been in greater demand of recent years. These species have become more available to mills through improved transportation and have been put to profitable use. These great forest resources yield an nually a production having a value estimated as high as 77 million dollars and giving employment to 100,000 persons (Bédard 1944a).

\section{Management}

It is safe to say that the forests of this territory, like those of most other parts of Canada and the United States, have been exploited without any provision for the future. Until recently no adequate forest management was practised. In general, the most valuable species are used, leaving the others as weed species. By clear-cutting operations, all the wood needed for a particular industry is cut-out, leaving the ground practically bare. Under such mismanagement merchantable timber becomes more and more remote and overmature forests deteriorate rapidly. The fire hazard is also much increased, the regeneration is slow and the second growth has a lower value. Even if the cutting methods are not always faulty the regeneration of the forest receives little attention. Serious problems have been created by the gradual destruction of the forest in the best regions of the Province of Quebec (Rousseau 1944). Some industrial centres will face, in the near future, the problem of shortage of raw material both for existing mills and for local needs.

\section{HISTORICAL NOTES}

Before discussing the main part of my subject I would like to give a brief historical summary of the work done in the past on forest pathology in the Province of Quebec. 
As in the United States and the rest of Canada, nothing significant was done in this field before the end of the last century. The forest was so generally ever-present and wood so cheap that there seemed to be no need for studying tree diseases. Moreover, primeval conditions were not sufficiently disturbed to cause serious troubles. In this respect our forests were in a better position than those of the eastern part of the United States, where most of the lands had been settled and markcd by human activities, except northern Maine.

The first forest tree disease to be noted in Quebec was the white pine blister rust in 1916. The authorities were alarmed by reports of the damage caused by this disease in the United States. No important steps, however, were taken to prevent the spread of this disease, except scouting on a small scale and the publication of an extension bulletin on this disease by $\mathrm{G}$. C. Piché (1917), Chief Forester of the Province of Quebec. Until recently only a few lectures at the Forestry School of Laval University have been devoted to forest pathology.

The first forest pathologist to visit Quebec was Professor H. Faull of the University of Toronto. Between 1915 and 1925 he made several trips throughout the Province and surveyed general forest conditions. He has made some interesting studies on the snow blight (Faull 1929), a disease which causes serious damage to some nurseries.

In 1923, McCallum started quite an extensive study on the decay of balsam fir in two regions of the Province of Quebec. His work is the first important contribution (McCallum 1928) in this field. The publication of a study on cultural characteristics of rotting fungi by Miss C. W. Fritz (1923) and the finding of the cause of the red heart rot of balsam (Faull and Mounce 1924), are also important events. The discovery in Quebec of the woodgate rust in scotch pine plantations was also made about that time. (McCallum 1929).

Since 1930, forest pathology has entered a new phase and researches have been undertaken in respect to various subjects by newly appointed federal and provincial forest pathologists.

PATHOLOGICAL PROBLEMS IN CONIFEROUS FORESTS

The pathological problems of coniferous forests are of first importance in Quebec and will be discussed at this point. These stands occupy the largest area and provide most of the annual harvest of softwood. DECAY

Several leaf parasites, especially rusts and leaf-casting organisms, are commonly present in this type of forest, but usually they do not cause very serious damage. Apart from forest fires and insect epidemics which occur sporadically, decaying fungi cause the greatest sustained losses in coniferous forests. These losses were estimated in the United States and in Canada by von Schrenck (1900), Meinecke (1916), Boyce (1923), Hubert (1931) and others.

Author's note: After this article was published I discovered that a brief investigation was mude in 1922 by W. E. Hiley in some forest limits in Quebec. A confidential report of this study was published by Price Brothers \& Co. Ltd. 
Spruces and pines in Quebec are mostly attacked by Fomes Pini (Thore) Lloyd as trunk rot and by Polyporus balsameus Pk., P. Schweintzii Fr., P. circinatus Fr. and Poria subacida (Pk.) Sacc. as butt rot (Pomerleau 1941 and Morais). Balsam fir is most commonly affected by Stereum sanguinolentum A. 8 S. as trunk rot and P. balsameus and Poria subacida as butt rat (Mc. Callum 1928). Another fungus is most commonly associated with brown cubical rot of balsam fir, but has not yet been determined. Hemlock, larch and cedar are also attacked by the same organisms.

The problems involved may be summarized as follows: 1.-To what ex. tent are our forests affected by rots? 2.-What are the factors which favor their development? 3.- What are their effects on the yield? 4.-What are the possibilities of reducing these losses?

Although important contributions have been made on this subject in the United States and Canada by Boyce (1932), McCallum (1928), Kaufert (1935), Spaulding and Hansbrough (1944a), much more research work must be done to find the correct answer to these questions, especially in our north country. Since 1938 we have undertaken to give as much attention as possible to this phase of forestry and we have planned to study the pathological aspects of our forests systematically. Each year, for such purposes, sample plots are selected on various sites in a special area. All the coniferous trees in these plots are carefully described and analysed for decay, growth, age, etc. We have already collected data from more than 10,000 trees, mostly in the vicinity of Quebec City. We expect to increase these investigations gradually and to cover the main sites of the various forest regions of the Province.

These accumulated data, properly analysed, will provide a sufficiently accurate picture of the extent of rots and their effect on tree production. These data will also furnish information on the influence of the various sites and other factors on the incidence and intensity of the decay. From these studies pathological rotation may be fixed, more exact correction factors for cull may be obtained, and principles for future silvicultural practices may be specified.

I do not intend to discuss these great problems fully, but I would like to mention a few facts which are already available, mostly concerning balsam fir. The fast-growing species, which tends to replace the primary mixed sprucefir stands, is very defective at a certain age and under special conditions. Trunk and butt rots, especially in the southern part of the Province and in the United States, are causing great damage, particularly on poor and dry sites and in second-growth stands coming up under the cover of birches and other deciduous trees. McCallum (1928), Kaufert (1935), Spaulding and Hansbrough (1944a) arrived at about the same conclusion on the rotation age of balsam fir which they fixed at 70 years. From our data the incidence and development of decay in the Canadian boreal forests are noticeably slower in the colder regions. Some significant differences in rot percentage can also be detected between various sites. 
The application of the results of these studies to forest management is possible in easily accessible stands. Even in the boreal forest, where no care is given to future stands during or after logging operations, selective cutting or proper rotation is recommended. The spruce budworm epidemic which presently threatens eastern Canadian forests and coniferous stands in the Northeastern United States is intimately associated with this problem.

Decay in standing spruce is generally much less serious than in balsam fir. This problem, however, has also to be carefully investigated if we are to have a fairly good knowledge of the behavior and effects of rotting organisms on these species. The data already collected from spruce are not yet completely analysed, but we know now that the incidence of butt rots varies considerably with site. Heavy losses from reduction of merchantable volume, from wind. fall, and even from killing of the tree by basal canker, are sometimes encountered under certain conditions such as dry, poor, shallow soil and old pastures. The way these butt-rotting fungi gain entrance into roots and the exact conditions which favor such infection should be better known, but investigations on -diseases of underground tree parts are very difficult to conduct.

Jack pine stands frequently suffer heavy losses through trunk rot caused by Fomes Pini, particularly when ground fires have left scars at the base of the trees. This species which forms pure stands after fire on dry sandy soil is frequently affected by three native gall rusts (Pomerleau 1942b) which seldom cause heavy damage.

\section{OTHER Diseases}

Besides deterioration of the wood of living trees by rotting fungi, the mast serious disease of conifers in Quebec is certainly the blister rust of white pine (Pomerleau 1932). This foreign parasite has spread all over this territory since its first appearance in 1916. Except in plantations the damage after 30 years is not very spectacular, yet closer observation reveals heavy losses in certain stands.

White pine does not extend far north of the limit of the deciduous forest and seldom forms important stands. Large trees do not seem to be very much affected by this disease in the boreal forest, but the young ones are rapidly attacked. This species will eventually disappear from the northern regions, where it remains as a relic (Dansereau 1944b), and from the marginal portion of the deciduous forest. This tree is not sufficiently prolific to justify control measures.

In the southwestern sections of the Province fine and valuable stands still exist on private lands. Some damage has already been noticed in such forests, but their protection is economically possible. The value of white pine as a source of revenue for farmers, and also its ability to thrive on poor and dry soil set aside as agricultural land, indicate that blister rust control should be considered an economic undertaking. 
Up to now no important eradication work has been undertaken in Quebec, nor in the rest of Canada. One forest nursery and a few large plantations were adequately protected under our supervision some years ago, and plans for the control of this disease are being made as post-war relief work.

Hartley, Boyce et al. (1933) mention dwarf mistletoes as the cause of the most serious diseases of western conifers in addition to decay. The only parasitic plant (Arceuthobium pusillum $\mathrm{Pk}$.) of this family which occurs in Quebec is of little importance (Pomerleau 1942a). Slight damage, however, has been noticed on poor black spruce sites, seldom on white spruce and jack pine in the deciduous zone, and never in the boreal spruce-balsam fir forest.

\section{Non.parasitic Diseases}

Our knowledge of non-parasitic diseases of conifers is limited. Effects of frost or drought are sometimes noticed in various parts of the country, but what exactly are the pathological problems created in the surrounding forest by logging operations, opening of the forest, agricultural settlement, fire and all other conditions which alter the balance of a forest region? I will not venture to discuss these here, but only wish to indicate that such problems exist and that they have hardly been touched to date. (Pomerleau 1944).

The industrial development of the Province of Quebec has not progressed without causing serious damage to trees and forests. Unlike many other countries manufacturing plants are often located in the middle of densely forested areas. Several smelters were erected during the last two decades in the northwestern part of Quebec (Pomerleau 1944). Large aluminum plants were established near water power, and electro-chemical plants have been built close to productive stands. No extensive damage by any of these industrial processes has yet been detected except pcrhaps on surrounding vegetation. Balsam fir is severely injured within two to five miles around smelters but no distant toxic effects have been observed. Dust from asbestos mines are also noxious to trees, especially coniferous ones in the neighbourhood of extracting mills. Fine quick lime dust escaping from a magnesium plant is said to affect surrounding trees. Although no great damage to the forest has yet been noticed, the problem of smoke injury still remains and must be carefully studied in a territory like Quebec, where electrical powers and mines are constantly developing.

\section{WoOd Deterioration}

Another pathological problem in our conferous forests is the deterioration of dead trees. Three agents are mainly responsible for the destruction of coniferous trees: fire, insect epidemics and wind. Enormous areas in this country are destroyed annually by firc. Insect epidemics, such as the European Spruce sawtly in the Gaspé Peninsula and the spruce budworm in Ontario and Western Quebe:, periodically pass over our forested land and leave species defoliated and dead. A large quantity of windthrown timber can be found on the forest floor in all sections of the Province. The possibility of salvag. ing this wood partly depends on its rate of deterioration under various condi- 
tions. Some studies were pursued by Riley (1935) and Skolko on insect and fre-killed timber, but they should be extended to other species and to sites in each forest region.

The rapidity of decay of logging slash in its relation to fire-hazard should also be carefully studied in Quebec, particularly in the boreal forest, where forest fires are frequent and most destructive. Spaulding and Hansbrough (1944b) have already blazed a trail in the matter of slash disposal.

In a country where a great part of the wood cut in the forest reaches the mills by water transportation loss from sinkage is sometimes heavy. The effects on floating duration of each kind of rot and the degree of rotting of each timber species should be carefully investigated.

The problems of deterioration and preservation of wood during its trans portation, storage or use are among those which require most immediate attention. Relatively few fungi attack softwood timber in Quebec. Fomes pinicola (Swartz) Cke., Stereum sanguinolentum Lenzites saepiaria (Wulf.) Fr., Fomes roseus (A. E S.) Cke., Lentinus lepideus Fr., Polyporus abietinus (Dicks.) Fr., Poria incrassata (B. \& C.) Burt. and Coniophora cerebella Pers., are the main fungi causing deterioration. Blue stain in pine and spruce causes depreciation of pulpwood and saw-timber. Methods of handling and preserving timber from the cutting operations to its final destination should be considerably improved.

PROBLEMS IN DECIDUOUS FORESTS

Deciduous trees represent a lesser volume of standing timber in Quebec than coniferous trees, but they are nevertheless an important natural resource not to be neglected. Some species, like yellow and white birch, are more and more in demand, and they will be easily accessible with the improvement of roads and other means of transportation. The use of hardwood as fuel and the important maple sugar industry increase the value of these species.

The prevalence of diseases affecting hardwood trees is greater than those attacking softwood. Several agents reduce their vitality, degrade the wood and even destroy it. It has been said that most of the hardwood species (beech, maple, yellow birch), being at the margin of their geographical range, cannot endure extreme conditions. To what extent this is true has yet to be demon. strated.

\section{Birch Diseases}

What appears to be the most serious problem at present under this head is the general decline of white and yellow birch in the deciduous zone of Quebec. The decadence of birch following logging operations of softwood has been noted for some time past. Spaulding and Macaloney (1931), Hall (1933) and others have studied the same problem in the United States and they are not able to attribute the cause of this trouble to any specific parasite or insect. On the other hand, Balch and Prebble (1940) in New Brunswick and Nash (1943) in Maine have expressed an opinion now generally held by foresters that the Bronze Birch Borer is responsible. This idea has gained in strength 
in the three or four years since the die-back has been found in virgin forests and in fully stocked stands.

During the last two years we have studied this problem and collected data from various sections of the Province of Quebec (Pomerleau 1944). The results of our findings may be summarized as follows: 1-The trouble is general in the deciduous zone of the Province and does not seem to exist in the undisturbed stands of the boreal forest. 2-The Bronze Birch Borer is not always present in trees showing symptoms of the disease and the proportion of trees with insect galleries increases in stands each year after the first observation. 3-No fungus has yet been found to be the cause of this general decline. 4-On wet sites the intensity of the damage seems to be greater. The primary cause of this trouble could hardly be attributed to a xylophagous insect. Recently Anderson (1944) has clearly shown that the Bronze Birch Borer does not attack a sound tree.

In my opinion a combination of adverse conditions would cause decadence aver an extensive territory. The symptoms and the effects of this disease are similar to those found in stands where conditions have been suddenly changed by logging. Severe drought, foliage insects, winter injury or the accumulated effects of all these conditions may account for this trouble. What is the future of these birch stands? Will the trees recover, at least those that are not too severely attacked, or will they continue to decline by reason' of the attack of leaf and xylophagous insects, fungi, etc.? No doubt greater losses could be avoided by the quick utilization of birch before it is ruined by decay and insects. But this is not always economically feasible.

Birch is also attacked by a number of parasitic diseases (Pomerleau 1942d). Nectria canker is quite prevalent under certain circumstances: old stands of white birch and yellow birch on elevations or on dry soil are sometimes highly affected. Poria obliqua (Pers.) Bres., Stereum Murrayi (B. \& C.) Burt., Pholiota squarrosoides Pk., Fomes igniarius (L.) Gill. and Armillaria mellea (Vahl.) Quél. are the most frequent causes of defects observed in these species. Dead wood of birches is often rejected as merchantable timber on account of a slight discoloration. This condition seems to develop because of the fermentation of sap in standing trees. No trace of fungi is found in wood so affected.

\section{MAPle Diseases}

One of the most important problems of forest pathology in hardwood forests is that of the sanitation of sugar maple, especially when used for sugar production. The annual output of maple sugar in Quebec varies from 20 to 25 million pounds, which is as much as that of all the United States. It is therefore quite urgent to take steps to conserve this source of income for the farmer.

A pathological survey (Pomerleau 1945a) of maple groves has revealed that 38 per cent of the maples are affected by canker or decay and 45 per cent are seriously wounded; 27 per cent are cankered and 30 per cent bear external 
signs of decay. Nectria and Eutypella cankers are responsible for the worst damage in the young stage; Fomes applanatus (Pers.) Walk., Ustilina vulgaris Tul., Polyporus glomeratus Pk., Armillaria mellea and Daedalea unicolor (Bull.) Fr., causing either decay or canker, or both, are more prevalent later. Fomes igniarius and Fomes connatus (Weim.) Gill. are also important heartrotting organisms.

Frost crack is the most frequent wound formed on maple, while sun scald causes serious trouble in the sapling stage. Mechanical injuries, especially those produced by ice and snnw, are frequent and increase the decay and canker hazard. In certain stands, however, the main source of infection is the death of companion sprouts, suckers and larger branches.

Although more research is required in this field sugar maple stands can be improved by a proper choice of sites, by the gradual suppressing of infected or susceptible trees, and by reducing the cause of mechanical injuries. When sugar maple is maintained or unsuitable sites climatic factors and diseases of various kinds will sooner or later cause serious damage. (Pomerleau 1945a).

\section{Diseases of Other Tree Species}

Associated with maple is beech, a most aggressive and rapid growing species. Unfortunately this tree is very defective. Through frost crack, sun scald, and branch breakage, rot and canker organisms, especially Fomes igniarius, Poly. porus glomeratus, Ustilina vulgaris, Nectria spp., its wood is often rendered warthless by the time it has reached merchantable size. Beech bark disease (Erhlich 1939) which proved so destructive in Nova Scotia and New Bruns. wick has not yet appeared in Quebec. Red maple, often considered as a weed species, is affected by the same diseases as sugar maple.

Until recently aspen was ignored in forest operations. Since it is now often utilized as lumber or pulpwood, its diseases are more significant. This species is sometimes heavily infected by Hypoxylon (Bier 1940) and Cenangium cankers; and Fomes igniarius rot soon eats it way through the wood. Conditions which favor these diseases should be carefully investigated. A leaf blight caused by Sclerotinia bifrons (Ell. \& Ererh.) Whetzel (Pomerleau 1940) was quite prevalent all over this Province some time ago during two successive years, but most of the trees recovered easily from this outbreak.

Black and white ash were severely affected more than 16 years ago, apparently by winter conditions on certain sites (Pomerleau 1944). These species have not recovered since that time. The commonest rot found on ash is caused by Fomes conchatus (Pers.) Gill.

Pathological Problems of Shade and Ornamental Trees

Although most forest tree diseases are also found on shade and ornamental trees, the pathological problems they present are somewhat different.

The commonest disorders of such trees may be traced to adverse atmospheric or soil conditions. Exotic species are especially sensitive to cold weather, either in winter or in spring. Winter drought is also the cause of serious damage to both deciduous and coniferous trees. Norway spruce, white cedar and a 
few other evergreens were severely affected lately (1944) by this cause. Similar conditions were also noticed some years ago on Manitoba maple, American ash, and more recently on clm. Bud freezing injuries and sun scald also cause frequent damage to young sugar maples (Pomerleau 1944).

Smoke injuries in cities or in the neighbourhood of industrial plants are now more frequent (Pomerleau 1944) : smelters, electro-chemical and perhaps aluminum plants are responsible for most of the damage. Dust from roads and from asbestos mines sometimes causes serious trouble.

Among native pathogens, Nectria spp., which cause canker on several tree species, especially on maple, may be considered as the worst. Wilt diseases, usually on trees weakened by adverse conditions, are frequent on maple and elm.

$U_{p}$ to last year (1944), no sign of the existence of the dreadful Dutch elm disease was ever traced in Quebec or in other parts of Canada. Since its discovery in August 1944 near Sorel (Pomerleau 1945b) infected trees have been found in a district about 45 miles wide along the St. Lawrence River. How this disease gained entrance into Canada has yet to be discovered. It does not seem, however, that it came from the infected areas around New York by the gradual expansion of the pathogen. There is a wide gap of 250 miles between the northern margin of the infected zone in United States and this new centre of distribution. Moreover, the occurrence of the European Scolytus multistriatus March. has not yet been noticed here, but only the native beetle (Hylurgopinus rufipes Eich.). If drastic measures are taken promptly the chance of eliminating this disease seem to be good.

May I also add a word on the status of the willow blight or scab which was so destructive in 1927 and again in 1935 in certain sections of Quebec? Apart from these two severe outbreaks the disease does not seem to have made any progress. By vegetative propagation of trees which have withstood two outbreaks of this disease it may be possible to create resistant strains of willow.

PROBLEMS IN FOREST NURSERIES AND PLANTATIONS

The pathological problems of the nurseries and plantations become increas. ingly important with the growing necessity of reforestation. In the opinion of well-advised foresters (Lussier 1944), considerable areas of Quebec should be returned to their natural function i.e., forest growing, when not suitable for agriculture, to be set aside for watershed protection, recreational use and erosion control. Artificial reforestation being inevitable on some forest land, nurseries and plantations should be maintained on the same economical basis as any current forestry practice.

The most important problem in Quebec tree nurseries is the damping off of coniferous seedlings. Every year from 20 to 40 per cent of the seedlings of spruce and red pine are killed by soil fungi belonging to the geni Pythium, Rhizoctonia and Fusarium. (Pomerleau 1934). Certain years the percentage may be as high as 90 even 100 per cent in spring-seeded beds. When germina. tion is delayed by a hot and dry spring followed by a very damp period 
in June, as was the case in 1934, such costly losses are to be expected. No perfect treatment has yet beef found to prevent damping-off, although fairly good results are obtained by spraying seed beds with acid solutions such as aluminum sulphate, zinc sulphate, or sulphuric acid (Pomerleau 1942c). This is now a current practice in Quebec nurseries. Heavy losses due to drought, excessive heat and frost frequently observed in nurseries can usually be prevented by better practices.

One of the heaviest losses encountered in most of the Quebec nurseries is the result of infection by the snow-blight disease (Pomerleau 1941). In some nurseries, especially when they are close to the coniferous forest, most of the spruce, firs and even cedars were affected by this disease and had to be burned. Fortunately an easy treatment discovered by Dr. Faull (1929) is efficient against this disease. Faull dormant spraying with lime sulphur has been established as a current control practice in these nurseries.

Leaf diseases of deciduous trees, such as leaf blister of elm (Pomerleau 1935) and oaks, tar spots of maple, leaf spots of elm (Pomerleau 1938) butternut, and leaf-rust of Carolina poplar are among others most frequently found. With care, sanitation and spraying, all these diseases can be avoided.

Recently a rust on mountain and mugho pines, presumably caused by Cronartium filamentosum (Pk.) Hedgc., was found in two nurseries. A canker caused by Nectria cinnabarina (Tode) Fr. (Jacques 1944), frequently brings heavy losses to Chinese elms.

The most dangerous disease yet observed is certainly the blister rust of white pine. Some trees have been completely ruined, others heavily damaged. For these reasons white pine is no longer recommended as planting stock. In my opinion it would be perfectly safe to establish white pine plantations on well chosen sites after Ribes eradication. Plantations of exotic species are not very extensive in Quebec. In some of them the woodgate rust of Scotch pine is quite prevalent, at least on susceptible trees which are covered by' galls and stunted. Close to severely infected trees there are resistant trees which are perfectly sound. What is this rust and where does it come from? Boyce (1944) recently discussed this question. A similar globose gall caused by Cronartium coleosporoides (D. \& H.) Art. (Pomerleau 1942a) on our own jack pine may be nothing else but the same rust.

With the exception of a few cases of heavy infection of needles by Coleosporium Solidaginis (Schw.) Thüm., red pine plantations have been until now healthy. Tympanis canker on red pine and Cytospora on Norway spruce and other cankers have not yet been found in Quebec plantations.

Plantations in their early stages are not always a complete success because planting stock, planting methods, and sites do not meet the necessary requirements. Excessive heat, drought, alternate frost and thawing are sometimes responsible for a partial or total failure.

\section{CONCLUSION}

This general and rapid glance at the pathological status of Quebec forests 
will prove sufficient, I hope, to illustrate the importance of the subject, and perhaps also the inadequacy of our knowledge. Compared with the scope of this problem it may be felt that very little has yet been done. This is un. fortunately true; but this is largely due to the small number of those engaged in the study of such problems. In the few years which have elapsed since the beginning of systematic research in forest pathology in Quebec, considerable data have been collected on the prevalence, the effects and the causes of the main diseases of trees in this immense area. Special studies have also been made in respect to several pathological subjects in nurseries, plantations and virgin forests in relation to surrounding factors. The possibilities of control have also been studied. All means are being taken to find and eradicate newly introduced parasites before they become widespread. In the near future it is expected that better and more complete information will be available for the proper management of our forests, the control of tree diseases in various kinds of forests, and for preservation of forest products. To fulfil this requirement research agencies must be immediately created or developed and many more forest pathologists must be trained and maintained in this work.

\section{LITERATURE CITED}

Anderson, R. F., 1944. Relation Between Host Condition and Attacks by the Bronze Birch Borer. Jour. of Economic Entomology. 37: 588-597.

Balch, R. E. and Prebble, J. S. 1940. The Bronze Birch Boer, and its relation to the dying of birch in New Brunswick forests. Forestry Chron. 16: 179-201.

Bédard, A. 1944 a. Forestry in Quebec. Can. Geogr. Jour. 28: 258-281. 1944 b. Le Milieu forestier. La Forêt. Ch. I: 13-39. Montréal.

Bier, J. E. 1940. The Hypoxylon canker of poplar. Can. Dept. Agr. Tech. Bull. No. 27: 1-40.

Boyce, J. S. 1923. A Study of decay in Douglas fir in the Pacific Northwest. U.S. Dept. Agr. Bull. 1163: 1-20.

1932. Deciy and other losses in Douglas fir in Western Oregon and Washington. U.S. Dept. Agr. Tech. Bull. 286: 1-59.

1943. Host Relationship and Distribution of Conifer Rusts in the United States and Canada. Trans. Conn. Acad. Arts and Sci. 35: 329. 482.

Dansereau, Picrre, 1944 a. Interpenetrating Climaxes in Quebec. Sci. 99: 426.427

1944 b. Les Erablières de la Gaspésie et les fluctuations du climat. Soc. Géogr. Québec et Mortréal, Bull. N.S. 3(1-12): 1-18.

Erhlich, John. 1939. The Beech bark disease. Can. Jour. Res. 10: 593-692.

Faull, J. H. 1929. A fungus disease of conifers related to the snow cover. Jour. Amold Arbo. 10: 3.8.

Faull, J. H. ${ }^{2}$ Mounce, I. 1924. Stereum sanguinolentum as the cause of "Sapin rouge" or red heart of balsam (Abstracts). Phyto. 14 (7) : 349. 
Fritz, C. W. 1923. Cultural criteria for the distribution of wood-destroying fungi. Roy. Soc. Can. Proc. and Trans. III, 17: 191-288.

Hall, R. C. Post-logging decadence in northern hardwoods. Univ. Mich. School Forestry Conserv. Bull. 3. 1933.

Halliday, W. E. D. 1937. A Forest classification for Canada. Forest Service, Dept. Int. Can. Bull. 89.

Hartley, C., Boyce, J. S. et al. 1933. The Progress of forest pathology. U.S. $73 \mathrm{rd}$. Cong. 1. st. Sess. Senate Doc. 12-Separate 28: 695-722.

Hubert, E. E. 1931. An Outline of Forest pathology. New York.

Jacques, Emile, 1944. Un chancre de l'orme de Sibérie. (Ulmus pumila) causé par le Nectria cinnabarina, (Tode) Fr. Ann. l'ACFAS. 10: 89.

Kaufert, F. 1935. Heart rot of balsam fir in the Lake States, with special ref. erence to forest management. Minn. Agr. Expt. Sta. Tech. Bull. 110: 1.27 .

Lussier, Omer. 1944. Problèmes d'après. guerre: Le Reboisement. La Forét Québécoise. 7: 293-294.

McCallum, A. W. 1928. Decay in balsam fir. Can. Dept. Agr. Bull. 104 (N.S.) : 1.25 .

1929. Woodgate rust in Canada. Can. Dept. Agr. Div. Bot. Rpt. Dom. Bot. 1928 36.39.

Meinecke, E. P. 1916. Forest pathology regulation. U.S. Dept. Agr. Bull. $275: 1.63$.

Nash, R. W., 1943. Damage by the Bronze Birch Borer in Maine. Maine For Serv. Bull. 13:1-12.

Piché, G. C. 1917. Nates sur la rouille vésiculeuse du pin blanc. Serv. For. Québec. Circ. No. 1: 1-10.

Pomerleau, René. 1932. Etat actuel de la rouille vésiculeuse du pin blanc dans le Québec. Soc. Qué. Protec. des Plantes. (24 e. Rapport) 160-195.

-1934. Fungi responsible conifers Damping-off in Berthierville forest nursery. Que. Soc. Protec. Plants (25-26th. reports).

-1935. Notes sur le Taphrina ulmi.. Ann. l'ACFAS. 1-.

-1938. Recherches sur le Gnomonia ulmea (Schw.) Thüm. Cont. Inst. Bot. l'Univ. Montréal. 31:1-139.

1940. Studies on the Ink spot disease of poplar. Can. Jour. of Res. 18C: $199-214$.

1941. Deux maladies des conifères en pépinière. La Forêt 2uébecoise. $3: 13.22$.

-1942 a. Le gui de l'épinette noire dans le Québec. Naturaliste Cana. dien. 69: 11-31.

1942 b. The Spherical gall rust of Jack pine. Myc. 34: 120-122.

-1942 c. Etude sur la fonte des semis de conifèes. Rev. Trim. Can. 28: 1.27 . 
1942 d. Liste annotée des maladies parasitaires des arbres observées dans le Québec. Serv. For. Québec.

Pomerleau, René. 1944. Observations sur quelques maladies non parasitaires des arbres dans le Québec. Can. Jour. of Res. 22C: 171-189.

-1945 a. Les Maladies de l'Erable à Sucre et leur Prévention. Serv. For. Bull. No. 11.

1945 b. Distribution de la Maladie Hollandaise de l'orme. Rev. Can. de Biol. 4(7): 116.117.

Pomerleau, René et Morais, Lucien. 1941. Les caries de l'épinette noire à Duchesnay. Ann. de l'ACFAS. 7: 103.

Riley, C. G., 1935. Investigations into rate of deterioration of insect-killed spruce on the Gaspé peninsula. Woodlands Sect. Can. Pulp Eo Paper Ass. 37 (3) : 151-152.

Rousseau, L. Z. 1944. La Forêt Québécoise. La Forêt. Ch. II: 41.79. Montréal.

Schrenk, H. von. 1900. Some disease of New England conifers. U.S. Dept. Agr. Div. Veg. Phys. and Path. Bull 25:1-58.

Spaulding, P. and Hansbrough, . JR. 1944 a. Decay in balsam fir in New Eng. land and New York. U.S. Dept. Agr. Tech. Bull. 872:1-30.

1944 b. Decay of logging Slash in the Northeast. U.S. Dept. Agr. Tech. Bull. 876.

Spaulding, P. and MacAloney, H. J. A Study of organic factors concerned in the decadence of birch on cuttover lands in northern New England. J. Forestry, 29: 1134-1149. 